available shipping and an intensified demand. The edition includes information on a number of timbers not in general use, if not entirely unutilizable in peace-time, which can, it is stated, be satisfactorily employed for various useful purposes under wartime conditions. A notable addition, which the wholesale destruction caused by the German bomber has rendered advisable, is information on the fireresisting properties of most of the species. These valuable data are the result of extensive experi. mental work carried out at the Laboratory. British grown timbers, we are told, as can be readily imagined, are now being employed in greater quantities and for very exacting purposes, and users are frequently at a loss to know how a particular species may best be utilized for some specified object for which imported timbers have been used in the past. It would be useful and interesting if a list could be made of the actual purposes throughout the country for which home-grown timbers are now being employed.

\section{Genes, Viruses and Proteins}

VoL. 9 of the Symposia on Quantitative Biology, published by the Biological Laboratory, Cold Spring Harbor, Long Island, has just appeared. It covers in about 300,000 words the immediate field of "Genes and Chromosomes"' indicated by its title, and also a wider range of recent research which can be related to the study of chromosome structure either technically or theoretically. There are thirty-four papers and discussions dealing with optical observations, including the use of the ultra-violet and electron microscopes, $\mathrm{X}$-ray experiments on cell-activity and ehromosome breakage, the theory of protein and nucleic acid structure and behaviour, the chemistry and mutations of viruses and genes, and finally the use of the heavy nitrogen isotope in the study of amino-acid exchanges. The series ends by a summary and review by H. J. Muller. This volume is remarkable not only for almost every contribution being new in detail of technique and observation, but also for the whole point of view having arisen from the converging development of genetics, cytology and chemistry during the last ten years.

\section{Electric Cables}

Mr. S. W. Mersom, of the Cable Makers' Association, devoted the greater part of his chairman's address to the Transmission Section of the Institution of Electrical Engineers (J. Inst. Elect. Eng., 89, Pt. 1, No. 13 ; 1942) to the subject of cable engineering, first making brief reference to the development of solid plastic materials and proceeding to the question of their application to the manufacture of cables. The fierce light thrown on the older dielectrics by competition from the synthetics has revealed the extraordinarily high qualities of rubber and paper, and in the face of this experience new materials cannot be accepted without the fullest assurance of at least as good service with economic advantage. Although chemists have worked hard on the subject, their products have yet to be proved superior or even equal to vulcanized rubber, but doubtless the apparently parallel paths of the rubber and plastics chemists will ultimately be found to converge, with great benefit to both. The address then dealt briefly with very high voltage cables, research and the much discussed question of standardization, and it was closed with an outline of the standing and responsibilities of the engineer in relation to society, sug- gesting that it is time the engineer took his fair share in responsibility for the control of affairs, for otherwise the most lucrative profession would be that of reaper and not cultivator, a process which, if carried too far, will choke the life out of any industry or nation permitting it.

\section{Heat Requirements of Buildings}

A valuable compendium of information has been issued by the Institution of Heating and Ventilating Engineers in a publication entitled "Recommendations for the Computation of Heat Requirements for Buildings" (Pp. iii +41. 1s. 9d.) This comprises a section of the guide to current practice which was recently compiled for the use of members, and it places at the disposal of all interested in the subject a most comprehensive collection of data strictly in accordance with present-day practice. The information is conveniently grouped in three parts. That on temperature-rise and rates of change gives the recommended values applicable to buildings ranging alphabetically from aircraft sheds to warehouses. The design of heating and ventilating installations has been, in recent years, greatly influenced by legislation affecting factories, and a special section has been devoted to this class of building. Heat transmittance co-efficients for walls, floors and roofs in a variety of materials constitute the second part, which also includes data as to the allowances to be made for height and for conditions of intermittent heating. The third part deals with conductivity data and the calculation of overall coefficients for composite walls, floors and roofs. Included in it is a table of thermal conductivity and resistivity of practically all the proprietary materials used in building construction. Much of the information given has been obtained from such independent sources as the National Physical Laboratory and the U.S. Bureau of Standards, and for the benefit of those unfamiliar with heat-loss calculations as applied to buildings a typical example is included.

\section{Long-Distance Telephony}

VOICE-FREQUENCY signalling and dialling in longdistance telephony forms the subject of a paper read before the Institution of Electrical Engineers by W. G. Radley and E. P. G. Wright. The paper first sets forth the reasons for modern methods of signalling and dialling over long-distance telephone circuits and for preferring the use of voice-frequency methods for these purposes. An outline is given of the technical problems involved in the design of voicefrequency signalling systems and the author deals with operating requirements as well as with receiver and system design. Reference is also made to the recommendations of the International Consultative Committee on Long-Distance Telephony regarding means of avoiding interference between different signalling systems on international connexions and a forecast is given of the future development of signalling and dialling over long-distance telephone circuits. An interesting table is included which compares the various long-distance signalling systems in great detail.

\section{The Yellow Fever Situation}

According to the Journal of the American Medical Association of January 10, owing to perfection of control methods initiated by Gorgas and Oswaldo 
Cruz, there have been no reports of yellow fever in Brazil or in the whole western hemisphere during 1941 or in the previous three years. Attention now centres on jungle yellow fever, which differs from urban yellow fever in that it is not transmitted by Aedes oegypti. Risk of yellow fever, however, will remain so long as the jungle type persists. It is no longer enough to accept clinical opinion, however experienced, for the diagnosis of yellow fever, but laboratory information by viscerotomy and protection tests is necessary. Vaccination has been carried out on a large scale with satisfactory results. The International Health Board of the Rockefeller Foundation continues to co-operate in the epidemiological and laboratory studies of the disease and in the preparation of vaccine.

\section{Seismology in the South-western Pacific}

DurING the past year, 1941, a now teleseismic station was established at Auckland, New Zealand. The station is equipped with a Milne-Shaw seismograph, and accurate time is maintained on the records. It is administered by the Dominion Observatory, Wellington (acting director, Mr. R. C. Hayes), as part of the New Zealand seismological service. The instrument was established with the co-operation of the Auckland Institute and Museum, and is operated by members of the Museum staff. This new station is proving of great value in the recording of earthquakes, not only in the New Zealand region, but also in the south-western Pacific generally.

\section{Rockefeller Medical Studentships}

THe Rockefeller Foundation is again offering twenty-five studentships to enable men or women to take part of their clinical courses at medical schools in the United States and Canada. The offer is made primarily to help students in schools which have suffered in consequence of enemy action, but suitable applications from all medical schools in England, Wales, Scotland and Northern Ireland will be welcomed. The studentships, which are tenable for two years, will cover all tuition fees, maintenance, etc., but not the cost of travel to and from America. Students must return to Great Britain in vorder to take their final examination. Application forms may be obtained from the Dean of the Medical Faculty or School and must be sent in only by the Dean not later than April 25.

\section{Journal of the Franklin Institute}

Is spite of the difficulties of Atlantic transport, copies of the principal American scientific journals continue to reach us. The Journal of the Franklin Institute is outstanding from those of general interest and the December 1941 number, including the index to Vol. 232, maintains the usual high standard and variety of interest. A paper by Carl van Doren on Franklin himself deals with the remarkable American after whom the Institute is named. His qualities as man of science, diplomatist, statesman, business man, economist, printer, humorist and wit, writer and sage are all surveyed. Two technical papers are followed by notes from the National Bureau of Standards and the Biochemical Research Foundation, and a lively group of notes on current topics and book reviews. The Journal is published monthly from the Franklin Institute in Philadelphia.

\section{Night Sky in March}

THE length of day and night will reach equality when the sun enters the vernal equinox on March 21d. 6h. U.T. The moon is full on March 3d. 0 h. $20 \mathrm{~m}$. and on March 2-3 there will be a total eclipse of the moon, visible at Greenwich. The circumstances of the eclipse are as follows :

\begin{tabular}{lccccc} 
Moon enters penumbra & $\ldots$ & March 2d. & $21 \mathrm{~h}$. & $27 \cdot 6 \mathrm{~m}$. \\
\multicolumn{1}{c}{, umbra } & $\ldots$ & $\ldots$ & 2 & 22 & $31 \cdot 3$ \\
Total eclipse begins & $\ldots$ & $\ldots$ & 2 & 23 & $33 \cdot 2$ \\
Middle of eclipse & $\ldots$ & $\ldots$ & 3 & 00 & $21 \cdot 5$ \\
Total eclipse ends & $\ldots$ & $\ldots$ & 3 & 01 & $09 \cdot 8$ \\
Moon leaves umbra & $\ldots$ & $\ldots$ & 3 & 02 & $11 \cdot 5$ \\
Moon leaves penumbra & $\ldots$ & 3 & 03 & $15 \cdot 0$
\end{tabular}

The moon is new on March 16d. 23h. $50 \mathrm{~m}$. and there will be a partial eclipse of the sun on March 16-17, invisible at Greenwich, visible only in the South Pacific and Antaretic Oceans.

The occultations of the planets by the moon are as follows: Venus on March 13d. 15h., Venus $2^{\circ}$ N.; Mercury on March 14d. 22h., Mercury $3^{\circ}$ S. ; Saturn on March 2ld. 15h., Saturn $3^{\circ}$ N. ; Mars on March 22d. 20h., Mars $7^{\circ}$ N. ; Jupiter on March 23d. 08h., Jupiter $5^{\circ}$ N. ; Mars and Neptune will be in conjunction on March 2d. 7h., Mars being $1 \cdot 6^{\circ} \mathrm{N}$. Mars, Jupiter and Saturn are well placed for observation during the month. Venus is a morning star, and in the middle of the month rises at $4 \mathrm{~h}$. $30 \mathrm{~m}$. Among the occultations of stars not fainter than mag. 4 , the following may be noted: March 4d. 1h. $22 \cdot 2 \mathrm{~m}$., $\beta$ Virginis ; March 22d. 18h. 41·3m., $\theta^{1}$ Tauri ; March 22d. 18h. 47.8m., $\theta^{2}$ Tauri.

\section{Announcements}

Lieut.-General A. G. L. McNaughton has been elected an honorary member of the Institution of Electrical Engineers. This distinction has been conferred upon General McNaughton, who was until recently commander of Canadian troops in Great Britain, in appreciation of the outstanding services rendered by him to promote the practical application of science to industry, in which respect his work on high-voltage research during his presidency of the Canadian National Research Council has been specially notable.

Coloner S. J. Thompson, governing director of Messrs. John Thompson, Ltd., Wolverhampton (water tube boilers, motor frame pressings, etc.), has been elected president of the Institution of Mechanical Engineers, in succession to Mr. W. A. Stanier, chief mechanical engineer of the London Midland and Scottish Railway, whose term of office has expired.

JoHN Sсотт Medals and Premiums of the American Philosophical Society have been awarded to Major Edwin H. Armstrong, professor of electrical engineering, Columbia University, for his work in frequency modulation in radio; and Robert R. Williams, chemical director, Bell Telephone Laboratories, for his work on thiamin (vitamin $B_{1}$ ).

ARrangements have been completed for the publication of a volume of "Essays in Anthropology" to be presented to Rai Bahadur Sarat Chandra Roy, the distinguished Indian worker in this field. A limited edition is being printed. Orders for copies, with remittance (Rs. 12), should be sent to Dr. D. N. Majumdar, Anthropology Laboratory, University of Lucknow. 